Peters

\title{
When Your Motherboard Replaces the Pearly Gates: Black Mirror and the Technology of Today and Tomorrow
}

This paper considers five episodes from Charlie Brooker's dystopian science fiction anthology series, Black Mirror (2011-present). The episodes selected are those that-as argued in this text-depict the role of technology as replacing that of religion. To build this claim, they will be compared to one another, to the Christian biblical concepts they mirror, and to historical events related to theological debates within Christianity. Throughout the history of Western civilization, Christian belief has played an important role in shaping cultural ideologies. For that reason, it could be argued that Christian ideas continue to penetrate our cultural narratives today, despite declining self-recognition in the West as religious or spiritual. Concepts of the afterlife, omniscience, vengeance, ostracism and eternal suffering spring up in some of the least expected places within popular culture today. This paper argues that Black Mirror depicts the materialization of these concepts through imagined worlds, thus signaling the modern-day specters of Christianity.

Keywords

BLACK MIRROR

SCIENCE FICTION

DYSTOPIAN FUTURES

TECHNOLOGY

CHRISTIANITY

CHRISTIAN THEOLOGY

HISTORY OF CHRISTIANITY

Date of reception: 04/03/2019

Date of acceptance: 28/12/2019

Rebecca Anne Peters is an interdisciplinary artist and researcher currently living and working in Barcelona where she is a doctoral candidate at Universitat Pompeu Fabra in the Department of Humanities. After completing an MFA in Fine Art at Goldsmiths, University of London in 2013, she went on to receive an MA in Psychosocial Studies from Birkbeck, University of London in 2014. Peters originates from the United States of America. 
humanity might finally overcome the

(Kafka, The Blue Octavo Notebooks, 1954)

\section{Technology, Black Mirror and Christianity}

Much has been written about the role that technology plays within contemporary culture, and its place within the destiny of humanity, oraccording to the taste of the particular author-the history of humanity (Harari 2014; Harari 2016; Hayles 1999; Mahon 2018; Roden 2015; Wertheim 2000). In his book, Homo Deus (2016), Harari writes that one of humanity's aims through technology is essentially to turn ourselves into gods ${ }^{1}$ - to make humans amortal-capable of dying, but only by tragic accident, and apart from such risk, able to live forever $(2016,54)$. Whether this objective is achieved, however, remains to be seen. Harari sites projects such as Google's subcompany Calico, or the Gilgamesh Project, whose stated aim is to solve death (2016). Mahon instead delves into the science of CRISPR-Cas9 and gene editing as one of the most likely sites of our collective upgrade towards something superhuman $(2018,78)$. Beyond everlasting life, technology offers the possibility of other upgrades to humanity and our collective power, some of which overlap with notions of divinity (Harari, 2016). One such power would be omniscience, something big data clearly hopes to tackle sooner rather than later (among other things). Harari goes as far as to say Dataism (the worship or prioritization of data over everything else-particularly over privacy) could easily become a technoreligion of the future $(2016,428)$. Writing twenty years ago, Wertheim (2000) already understood the importance of cyberspace as a new space-one which many believe holds the key to everlasting life-a place in which physicality of the body.

Within his dark vision of the future in Black Mirror (2011-present), Charlie Brooker, the show's creator, highlights a number of ways that late capitalistic societies are already using technology towards these ends, and some of the ways we might use it in the very near future. As an anthology series, each episode of Black Mirror, co-produced by Brooker and Annabel Jones, tells a different story, independent from the others. Instead of a traditional narrative arch, overlapping characters, and a singular world that hold together most television shows, the episodes of Black Mirror are connected by their overarching message, genre, and subject matter. For that reason, the show lies somewhere between television and traditional cinema. The format of Black Mirror itself implicitly provides the rationalization to consider its overlapping themes when analyzing the show, as we look for insight into Brooker's vision of our relationship with technology. In an interview with Channel 4 in 2014, he said that "it's a worried show, it's a show that's worried about today-even though it's often set in near futures, or sort of allegorical futures, it's really always about now, and what's going on now."

The episodes of Black Mirror take place in a future between now and, as Brooker put it, "10 minutes' time, if we're clumsy" (Brooker 2011). The worlds that he creates throughout the show can be described as dystopian futures, though some of the episodes could easily take place today. His overall message, as we can glean from the quotes above, is that the technologies we have, or will soon have, could bring with them grave consequences. For anyone who has seen the show, that is probably a serious understatement. I would argue, that Brooker's Black Mirror does not highlight the inherent dangers of technology itself, but instead 
the dangerous ways that we might put that technology to use, given our current trajectory and the ways that we already use it to relate to one another and ourselves. Throughout Black Mirror, Brooker uses slight variations from our real relationships with technology in a way that makes alarmingly clear the dangers of our current path.

Although not overtly referencing religion, Black Mirror highlights questions regarding the god-like powers mentioned at the start of this section. Additionally, when we start looking at the show through the lens of Christian concepts, other parallels become clear. ${ }^{3}$ This paper will demonstrate that we can also see overlapping themes with some of the darker realities of Christianity (including notions of just punishment, ostracism, and eternal suffering). Taken together, we see the lingering specter of Christian thought, and many of its worst characteristics played out in some of the episodes of the series. These themes - of technology making humanity truly god-like or its potential to allow us to carry out the social constraints often found in religion-are not overt in all of the episodes of Black Mirror, but there is a strong theme throughout many of the episodes that is hard to ignore.

Harari (2016) argues that the apparent connection between the attributes of deities and the characteristics we are aiming to acquire exists not because we are haunted by religious ideas, but instead because humans have always desired those god-like qualities. He suggests that our creation of gods with superhuman powers and immortality came because we wished for those things but were unable to fulfill them. In other words, we want to live forever and have super-human powers-and we always have. In the past, humanity projected these desires onto the gods; within Christianity the institution of the church decided who would have access to eternity, but now there is no need when technology might soon bring these dreams to realization (Harari, 2016). If these were the only types of possible worlds Brooker imagined in Black Mirror, it might be possible to disregard the connection between religion and technology in the series as Harari's theory could be made to do.

However, while Black Mirror includes these "technology makes gods" manifestations (which will be considered in-depth in section II), it also considers a more problematic possible future, one that is harder to excuse as simply a timeless human desire, but instead one where technology plays the role of moral enforcer. In other words, some episodes of Black Mirror depict future worlds where it could be argued that technology allows for the manifestation of Christian concepts of divine punishment, ostracism, or eternal suffering. Brooker seems to be suggesting that the ghosts of Christianity are harder to shake than many would like to believe. We will consider these later examples in section III, building the argument that the series sees religion, or at least its specter, as something which continues to influence culture and the technology of today and tomorrow-and above all as something we should be weary of in its potential to impact our trajectory.

This article argues that Black Mirror depicts technology as a sort of replacement of religion (in this article I specifically consider Christianity), not only in the role of the Christian God, but also in the role of the church as an institution. In sections II and III, specific episodes will be analyzed for their depiction of similarities between technology and notions of divinity (section II) as well as religion as a social enforcer (section III). Likewise, I will briefly compare related current events when appropriate to help to solidify the comparisons between the technology we see in these episodes of Black 
Mirror and the specter of religion that continues to inform Western culture today.

\section{Technology makes gods}

As discussed at the start of the introduction, technology's important role within the future of humanity seems obvious, but how that relationship is playing out is widely discussed and disputed among historians and philosophers alike (Harari 2014; Harari 2016; Hayes 1999; Mahon 2018; Roden 2015; Wertheim 2000). As detailed above, one of Harari's predictions is that we will collectively aim to overcome death, and that it will be among the three important goals we set out for ourselves over the next century (Harari 2014; Harari 2016). He bases his thinking on research that is already being done to extend life combined with the ease by which we already permit the use of curative treatments as preventative ones (Harari 2016, 60). Likewise, Wertheim considers cyberspace and its relationship to Christian ideas. She writes:

"... the cybernautic imagination is rapidly becoming a powerful force in its own right ... Yet, as I will suggest here, many of these fantasies are not new-in essence they are repackagings of age-old Christian visions in technological format" $(2000,21)$

While considering Benedikt's Cyberspace: First Steps (1991) and Moravec's Mind Children (1988) among other writing on cyberspace and its potential as a means of overcoming death, Wertheim explores the early thinking on how cyberspace might help us to overcome our mortality and asserts that these collective aims need to be explored as they could come to define the development and use of future technology (Wertheim 2000, 43).
Harari takes the argument one step further in his assertion, writing that our collective aim to overcome death is not based on spiritual ideals (for instance, gods that are immortal or the notion of a heavenly afterlife), but instead he argues that we invented gods because it was already our desire to conquer death. We no longer need belief in deities because we are rapidly gaining the tools to overcome death ourselves (Harari 2016). Thus, he argues that these concepts come from a common human desire, and although they seem to relate to one another (ideas about gods and our attempts towards god-like powers), this similarity is only due to their common root. This argument works when we think about positive concepts such as everlasting life or omniscience, but it runs into issues when it comes to the darker Christian concepts that will be considered later in this paper (section III).

I will first consider these positive religious concepts as they play out within Black Mirror, as a starting point to draw connections between the Christian concepts and the content of the show. In particular, I will start with the episode "San Junipero" (2016) as it has been tied to notions of heaven and an afterlife by both the show's creator and in academic discourse (Brooker and Jones 2018; Drage 2018; Constant 2018). Following the discussion of "San Junipero" I will also consider "Hang the DJ" (2017) and the god-like, omniscient power of big data.

$$
\begin{aligned}
& \text { Everlasting Life in "San Junipero" } \\
& \text { — Scheduled to pass. } \\
& \text { — Let's just call it dying. } \\
& \text { - If you can call it dying. } \\
& \text { - Uploaded to the cloud, sounds }
\end{aligned}
$$
$(2016)^{4}$ like heaven.

- I guess. 
Fig. 1: "San Junipero," Black Mirror (2016)

12

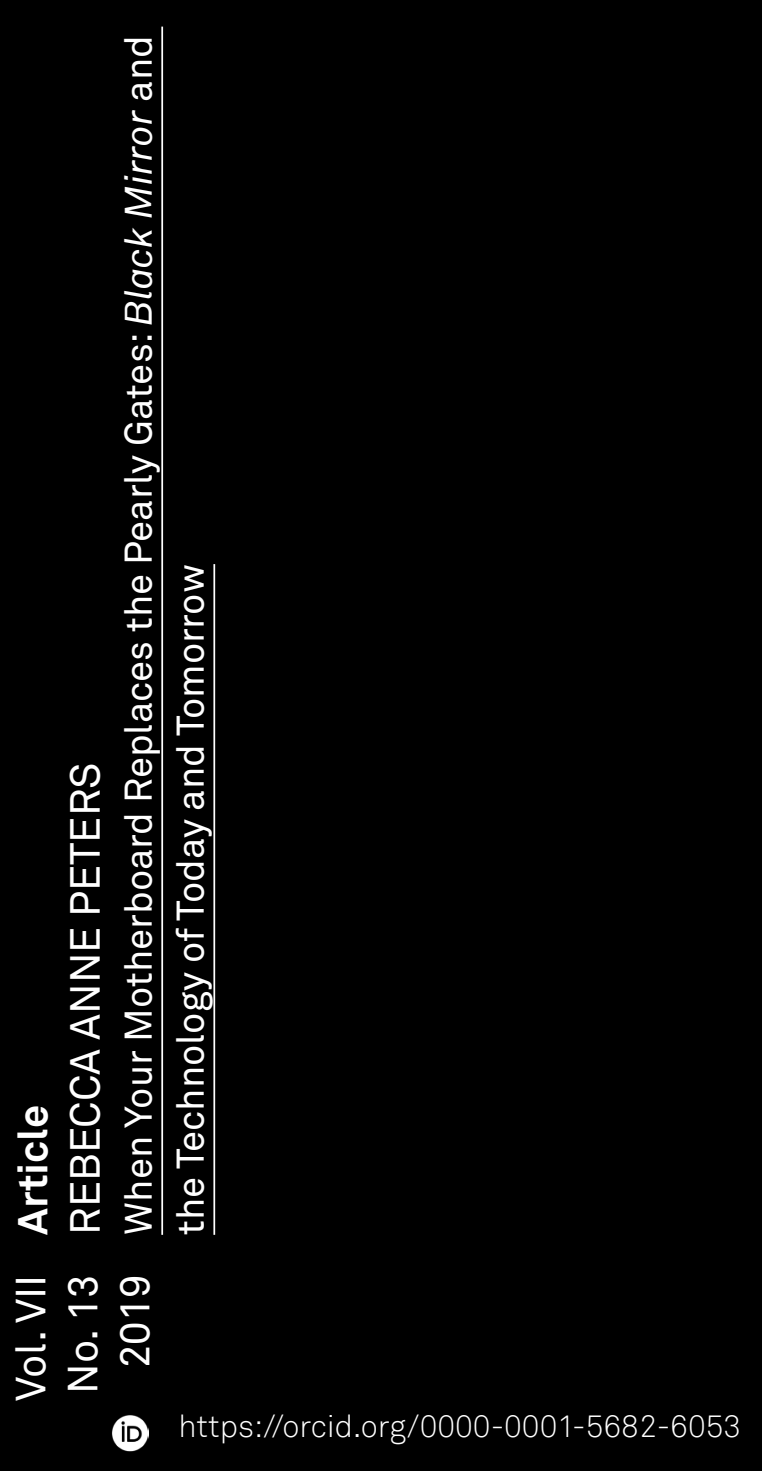


San Junipero is a virtual world that the elderly are allowed to visit for a rationed amount of time each week (usually 5 hours on a Saturday night). While visiting, they are young, and can presumably choose to spend their allotted hours in any time period they desire. In the episode we primarily see the 1980s, although we also see brief switches to the 90 s and the early 2000 s. Once they die, they have the choice to stay in San Junipero forever, an everlasting life of youth without death or aging; they can even turn off their pain sensors for a painless existenceat least in the physical sense. It could be called heaven on a server; it is certainly depicted that way. In the closing scene of the episode, we see a long cross fade between the experienced reality of the residents of San Junipero, and their tangible resting place-as files on a server (Fig. 1).

Drage (2018) considers San Junipero a heterotopian graveyard (in the Foucauldian sense), and though we do not take our analysis in the same direction, her consideration of "San Junipero" as depicting a sort of afterlife gives foundation to the reading of the episode in this way. Likewise, Brooker considers "San Junipero" from a similar angle saying: "I'd been obsessed with doing a story about the afterlife" (Brooker and Jones 2018).

The comparison of San Junipero to heaven is brought up in the episode itself, with one of the main characters, Kelly (Gugu Mbatha-Raw/Denise Burse), sarcastically saying, "[u]ploaded to the cloud, sounds like heaven" while discussing the upcoming, scheduled death of the episode's other leading lady, Yorkie (Mackenzie Davis/Annabel Davis). Likewise, the song "Heaven is a Place on Earth" by Belinda Carlisle plays both at the start and end of the episode.

The story follows Yorkie, who we first see timidly engaging with other young people in a bar in San Junipero. We later discover that she's in a coma and has been since her early 20 s, following a car accident after a fight with her parents when she came out to them as gay. Her parents, who are deeply religious, refuse to allow her life to be ended, even though it is what Yorkie has made clear she wants. The biblical concept of an afterlife is further emphasized through Yorkie's broken and old physical body. Christianity teaches that heaven is a place where everyone will be renewed, given new immortal bodies - that in resurrection the faithful will defeat death. This concept of transcending the physical body is also something discussed by Wertheim in her description of the potential of cyberspace, which she posits has the possibility to eliminate bias because among other things the "ageing body is hidden from view behind the screen" (2000, 25).

We can read throughout 1 Corinthians 15 about this notion of the renewal of the body-the transformation of the body in our life after death:

"The sun has one kind of splendor, the moon another and the stars another; and star differs from star in splendor. So will it be with the resurrection of the dead. The body that is sown is perishable, it is raised imperishable; it is sown in dishonor, it is raised in glory; it is sown in weakness, it is raised in power; it is sown a natural body, it is raised a spiritual body. If there is a natural body, there is also a spiritual body" (1 Cor 15:41-44 NIV).

Thus, we are told that death will be conquered and that after death we will be remade to be imperishable, immortal, and strong.

“Listen, I tell you a mystery: We will not all sleep, but we will all be changed-in a flash, in the twinkling 
of an eye, at the last trumpet. For the trumpet will sound, the dead will be raised imperishable, and we will be changed. For the perishable must clothe itself with the imperishable, and the mortal with immortality. When the perishable has been clothed with the imperishable, and the mortal with immortality, then the saying that is written will come true: 'Death has been swallowed up in victory"' (1 Cor 15:51-54 NIV).

This biblical parallel to a heavenly afterlife, then, seems to be a possible reading, among others, when we consider "San Junipero." Obviously, there are many details of the episode that contradict traditional Christian teaching, but by their contrast these details highlight the connection between the Christian conception of heaven and the one on screen. Drage's (2018) interpretation of the episode, for example, considers more closely the same sex relationship between Yorkie and Kelly, while Constant (2018) also analyzing "San Junipero" from a Foucauldian perspective, focuses on a reading of the use of mirrors within the episode. Though the episode does not make clear all of the details of the mechanisms that make San Junipero possible, Constant (2018) briefly considers the possibility that they could hold more sinister secrets below the surface:

“... New ethical questions arise regarding surveillance in this new type of space-could San Junipero be a new 'panopticon'? Perhaps Brooker offers one clue: in the last scene of the episode in the server room (the mirror), both Kelly and Yorkie's discs are stamped with the letters 'TCKR:' could this indicate that San Junipero is the product of a private corporation?" (Constant 2018, 575).
After looking at the parallels between the afterlife shown on the screen in "San Junipero" and the one described in the biblical texts, we should also consider some history regarding the church and the messy relationship between money and salvation that has plagued Christianity and caused schisms among its denominations, specifically the Catholic belief in indulgences and the prosperity gospel preached by some Protestants today.

We could consider a parallel between the episode and the abuse of indulgences within the Catholic church, which famously led to the Protestant Reformation in the early 16 th century. The belief in indulgences still exists today within the Catholic Church, and Catholics can still be issued indulgences to be used for themselves or in the name of others, to avoid time spent in purgatory (Moorman 2017). Martin Luther saw abuse in the system, with clergy selling indulgences, giving those who are able to purchase salvation a means of avoiding true penance (Russell 2017).

For a modern-day example of how money and salvation come together, we might look at the prosperity gospel within the context of the United States. Generally speaking, the belief posits that those who do good, and donate money to religious causes will be blessed by God with health and wealth, a belief often preached by televangelists, and an idea taken to heart by millions of Americans (Bowler 2018). Once again, we see money coming into the equation when it comes to faith and the physical body, but this time related to our time here on earth. Not tied exclusively to one particular Protestant denomination within Christianity, the prosperity gospel instead is tied together through a common message: "God desires to bless you" as discussed by Bowler in her book, Blessed: A History of the 
American Prosperity Gospel $(2018,6)$. The prosperity gospel has been heavily criticized as a means of exploiting the poor into donating money which goes to the enrichment of select church leaders, but supporters of the movement say that these church leaders should also be blessed by God and that their wealth is merely a reflection of that blessing.

In both cases, with the sale of indulgences in the Catholic Church in the early 16 th century and the belief in the prosperity gospel today, we see how easy it is for money and greed to seep into Christian doctrine. It is not hard to see small glimpses of how money might also affect the virtual heaven depicted in "San Junipero." We might only be seeing a naive perspective of this "heaven on a server" in the episode itself. The two main characters in the episode are both in very nice care facilities, Yorkie in a hospital, and Kelly in an elderly care facility. Likewise, the parts of the real world we see are clean and, in some ways, luxurious. Finally, we see that the servers hosting San Junipero and its residents are owned by a big company, TCKR Systems, as we saw highlighted earlier by Constant (2018). Might the rich be the only ones who can afford to enter the digital afterlife we see on the screen? Wertheim considers the issue of money and privilege while writing about cyberspace as a possible space for life after death:

"Just as the New Jerusalem is open to all who follow the way of Christ, so cyberspace is open to anyone who can afford a personal computer and a monthly Internet access fee ... The problem is that, unlike Heaven, access to cyberspace depends on access to technologies that for vast swathes of the world population remain firmly out of reach" (Wertheim 2000, 25). However, as we will see later in this article, in the world of Black Mirror, these digital versions of a person can coexist with the original, making them a duplicate, leading us to question whether San Junipero is truly an escape from death for the original, or if the differentiation between the two really matters.

Further exploration should be done on the concept of life after physical death within Black Mirror, specifically in "Black Museum" (2017) where we see technology that allows one consciousness to be embedded alongside another. Alternately, "USS Callister" (2017) shows a group of digital duplicates escaping their captive and presumably living a never-ending alternate digital life, separate from their original one. These episodes would certainly offer further insight into this theme when looking at the show as a whole.

Omniscience through an all-knowing algorithm in "Hang the DJ" (2017)

- [DEVICE] Congratulations, Amy. Your ultimate match has been identified. Your pairing day is tomorrow.

- Ultimate as in "the one"?

- [DEVICE] That is correct.

"Hang the DJ" follows two young twenty-somethings, Amy (Georgina Campbell) and Frank (Joe Cole), as they follow a system to find their "ultimate match" - a system that boasts a $99.8 \%$ success rate. Presumably inside a dating center, the site is specifically meant to allow participants to find their match, equipped with everything they need-including temporary housing. An algorithm, or coach as it is referred to in the episode, pairs off matches for specific amounts of time, using these temporary relationships to collect data in order to identify each user's ideal match. The two, Amy and Frank, are paired off for a brief encounter, leaving both wanting more. 

After being paired with others for relationships of various lengths, Amy and Frank are paired with one another for a second time, and they agree not to check the designated length of their relationship as decided by the algorithm - information which users are free to access. When Frank decides he must know how long he has left with Amy, and checks the countdown timer alone, his "one sided-observation" leads to a recalibration of the relationship length - a drastically shortened time together (Fig. 2). They will have just 20 hours from what should have been five more years, and the relationship ends with a fight between the two about the broken promise.

Once again, the two are assigned new relationships, and eventually both are told that their ultimate match has been identified-and that they have not previously met the person with whom they will be matched. When they are given the chance to say goodbye to each other at the same restaurant of their first pairing, they decide that they do not want an ultimate match, but each other. They try to escape the complex, and it is revealed that they are not inside a center at all, but a simulation. The scene depicts the two scaling a wall into the heavens, and then they are just in darkness (Fig. 3).

Thus, their rebellion was an anticipated, desired response-a test. One simulation of 1,000 run on this particular couple; in 998 of those simulations they choose to escape together-thus the $99.8 \%$ success rate they are told the system has achieved. The episode ends with the two meeting in real life, having received the same near perfect match on a dating app.

Christianity ascribes many positive characteristics to their God: omniscient, all powerful, loving creator of the world. "He determines the number of the stars and calls them each by name. Great is our Lord and mighty in power; his understanding has no limit!" (Psalm 147:4-5 NIV). This assertion that the Christian God is omniscient, while foundational and seemingly straightforward, has caused widespread debate between religious scholars and students of theology. There are two general theories within the debate, Calvinism and Arminianism. ${ }^{6}$ However, in the late 20th and early 21st century, a third theory came into the spotlight, with a view of God as all-knowing, but in a different sort of way (Beilby and Eddy 2001). The new theory, Open Theism, has been so controversial that academics writing about it have been shunned from their Christian universities (Smith 2018). What could be so controversial about the theory?

Open Theism, put simply, is a belief system that views God as all-knowing in an "open" sense. Instead of knowing everything in the more classical view of omniscience, God knows both everything that has already happened (in a certain, closed sense) and those things that have not yet happened in an open sense (i.e. God knows what could happen, including every possibility and the fullness of the consequences of each possibility). The grand biblical plan is fixed or known, but there still remains possibility for openness, for free will: "[r]eality in other words, is composed of both settled and open aspects. Since God knows all of reality perfectly, this view holds that he knows the possible aspects as possible and knows the settled aspects as settled" (Boyd 2001, 14).

From my understanding of the theory, the basic principle is that when we come to a choice and make it, God knows beforehand the likelihood of our choosing any of the options; thus we do not surprise God with our free will, but he does not choose our actions for us either. Once we make each choice, the likelihood of our future choices is reconsidered; we 
follow a different part of the spider web of knowledge, and His knowledge of our path updates, if you will. Put simply, one could argue that open theists believe that God has hacked our habits and choices-God as the ultimate collector of big data.

That being said, does the reverse hold true? Is big data god-like in some way? With knowledge of our past purchasing and viewing histories, companies like Amazon and Facebook individually target users with personalized ads. Later based on the ads you click on, or the things you go on to purchase, you will see different ads the next time you are viewing-cookies, online tracking, and device fingerprinting even mean that companies have the ability to track your habits between devices. That means that Amazon's "Recommended for you" is all-knowing in the Open Theism sense-the past is known and closed, but future choices are infinite, though with probable odds based on past behavior. This strangely similar model makes clear just one way that technology has begun to tangibly stand in for religion in the world today. With click through rates and adaptive targeting working to get us all to spend more money, we see just one way that our shift away from religion in the West manifests itself in the worship of other things. And our consumer behavior is the tip of the iceberg in the near-future dystopia anthology series Black Mirror.

We can see then, how the comparison between a Christian omniscient God is not such a distant concept when compared to the algorithm controlling the dating system in "Hang the DJ"- both know what has come before, and while not completely certain, both can make increasingly accurate assumptions about the future. Black Mirror depicts our willingness to put our full faith in data, our desire for all-knowing technology to solve our problems, and our readiness to concede privacy for ease. Harari (2016) takes the leap to suggest Dataism might one day be, as he calls it, a techno-religion. Similarly, Wertheim discusses the fantasy of omniscience in relation to cyberspace showing us the possibility for exclusion that this worship of data might hold when asking again "who will have access to these resources?" (2000, 29).

We could equally consider the allknowing algorithms in other Black Mirror episodes including "Fifteen Million Merits" (2011) or "Nosedive" (2016). Likewise, we can see the allknowing attribute brought down to an individual level with perfect memory archives in "The Entire History of You" (2011) or "Arkangel" (2017). Each of these episodes should be considered further in the context of omniscience.

\section{Technology as despot}

This section will focus on the role that technology plays within Black Mirror as a moral enforcer-specifically considering the overlap between technology and religion on topics of public punishment, ostracism, and eternal suffering. These concepts, seemingly borrowed from Christianity, play out within Black Mirror highlighting the parallels between these religious ideals and notions of justice and punishment within the series.

When viewed in isolation, these episodes might seem to simply depict a future where punishment is taken just a few steps further than what we see today. It is not so hard to image these scenarios taking place in real life should such technology become available. After all, the death penalty is still widely used within the United States, and public executions in Europe were still taking place less than 100 years ago (Bessel 2015).

While many of the biblical references used throughout this section are drawn from the Old Testament, questions 
regarding punishment, torture, and execution are still widely debated issues within Christianity today, as is the question of rehabilitation and reconciliation (Snyder 2000; Durrant and Poppelwell 2017; McConville 2003). These themes seem to be interpreted more on an individual basis instead of a sweeping denominational one; though the Catholic Church has recently redefined their stance on the issue of the death penalty, which has gone back and forth since the mid-20th century (Holy See Press Office 2018). That being said, it is important to acknowledge the emphasis on the Old Testament writings within this section, while acknowledging that many Christians believe they should be read in the context of the New Testament writings. Even with this consideration, as stated above, there seems to be no clear consensus on many issues surrounding punishment even when we reconsider the Old Testament read through the lens of the New Testament.

The episodes in this section encompass small details, just as the two considered in section II, that bring their content closer to these Christian concepts than simple coincidence. These details: a mob member shouting "burn in hell" or the notion that justice on Christmas is particularly satisfying, highlight the minute details that could be used to justify the reading of these episodes as more than just coincidentally similar to Christian concepts. The following subsections will consider the Black Mirror episodes "White Bear" (2013), "White Christmas" (2014) and "Men Against Fire" (2016).

Public punishment for the wicked in "White Bear" (2013)"

- [news coverage] The jury was not convinced by Skillane's story and neither was the judge, who labeled her a uniquely wicked and poisonous individual. "You were an enthusiastic spectator to Jemima's suffering. You actively reveled in her anguish" he said... adding her punishment would be proportionate and considered. By hanging himself in his cell, many believe lain Rannoch evaded justice. The public mood is now focused on ensuring his accomplice can't do the same. Patrick Lacey, UKN.

- [wailing]

- Oh, don't start crying. Crocodile tears are making me sick!

\section{— [audience] Murderer! Murderer!}

Presumably after a failed suicide attempt, Victoria Skillane (Lenora Crichlow) wakes up in a house she does not recognize, without any recollection of who she is, or any of the specifics of her life. However, she quickly realizes that she has found herself in a world of chaos and violence. She comes to discover that a radio signal transmitted through cellular phones has made a large portion of the population docile and only interested in recording the actions of others on their mobile devices. Most alarmingly however, those not affected by the radio signal have fallen into two different groups: those who are seizing the opportunity to take advantage of others (through torturing and killing), and those who do not wish to harm others but instead are preyed upon (it is suggested that they are more mentally vulnerable).

Throughout her attempt to flee the situation, Skillane witnesses horrific things, and is nearly murdered a number of times. Finally, she and her newfound guide, Jem (Tuppence Middleton), arrive at the radio tower Jem plans to burn down, and Skillane is forced to shoot at one of the attackers pursuing them. At this pivotal moment, in full theatrical revelation, the viewer (along with Skillane herself) discovers that everything in the episode up until that point has been a highly fabricated fiction-a daily punishment for 
Skillane's role in the murder of a small girl. Skillane is shown the details of the murder, along with the audience (both the viewers of the episode, and those of the spectacle itself). Finally, she is taken to be harassed publicly and then to have her memory erased-an event that is extremely painful and happens daily. During the credits we find out that her punishment is marketed and attended as a sort of theme park of justice, where the public can come to participate and witness Skillane's fate.

Skillane's memory is erased every evening, and she is forced to live the same terrifying day over and over as punishment for her crimes. For most of each day, she doesn't know who she is, or even what she has done. In the episode they mention that Skillane's boyfriend "evaded justice" by killing himself-as detailed in the dialogue from the episode used as the opening of this subsection. Thus, death is not enough; instead what is desired is public punishment and public shaming - the lure of the stocks, pillories, and public executions. But alarmingly, we see that it does not matter whether she remembers committing the crime or whether she feels sorrow for what she has done when she discovers it-it is not about penance or rehabilitation, it is about punishment and retribution.

In "White Bear" the idea of divine justice is played out within the law through the use of technology as a form of public punishment. When Skillane is driven back to the house where she will once again begin her punishment the following day, mobs of spectators yell at her, throw things at the clear trailer she is transported in, and the whole event is part of the experience of the theme park - all sensationally led by the theme park employees. We hear people shouting "Murderer!" and "Burn in hell!"-a further detail supporting the idea that Brooker is himself troubled by these specters of Christianity, particularly in relation to notions of justice.

This religious element within criminal justice is something we have seen throughout the history of Christianity, however. Jones and Johnstone write:

"The roots of Western civilization reach deep into antiquity, as do the problems of crime and punishment ... The vast treasury of the Bible provides a rich heritage of history, theology and philosophy that has had a persistent impact upon modern society" $(2015,15)$.

The long and intertwined relationship between religion and criminal justice has roots that span history dating back to biblical Israel and continuing through today.

"Of course, there is a moral dimension to the definition of crime ... It [religious belief] has been, and in many societies continues to be, the major source of ethical and behavioral rules. Not surprisingly, when legislators or judges participate in the lawmaking process, they are strongly influenced by their religious beliefs. Every rule or criminal law thus has a moral dimension derived in large measure from cultural views concerning theology" (Jones and Johnstone 2015, 9).

Then, it is no large leap to suggest that the creation of technology meant to punish those who have committed crimes, might also reflect a religious element or mirror biblical punishment. We will look at colonial forms of public punishment later in this section and consider the church's role in punishment.

Convicted of murder, Skillane lives the same day over and over again in 


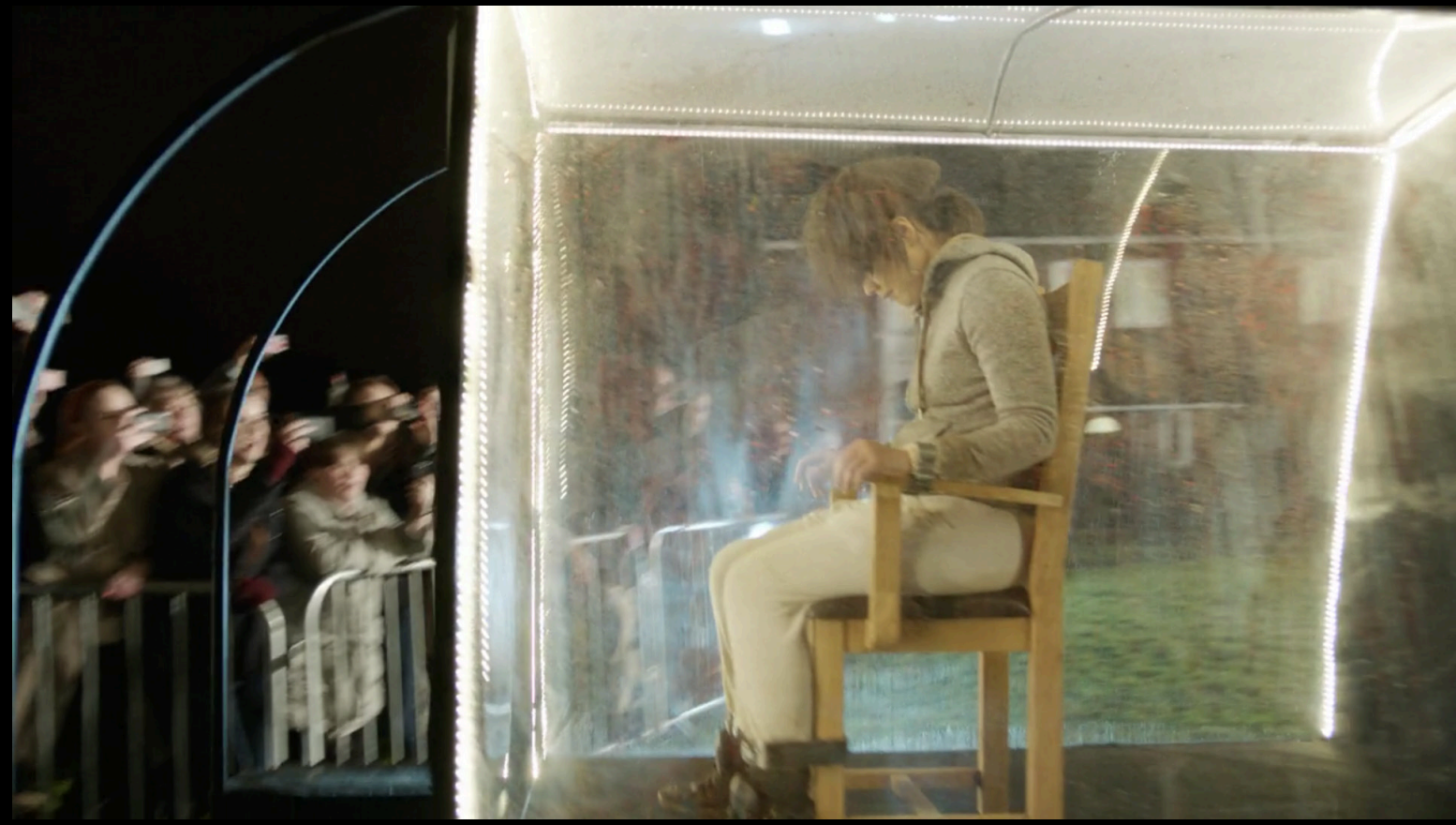

Fig. 4: "White Bear," Black Mirror (2013)

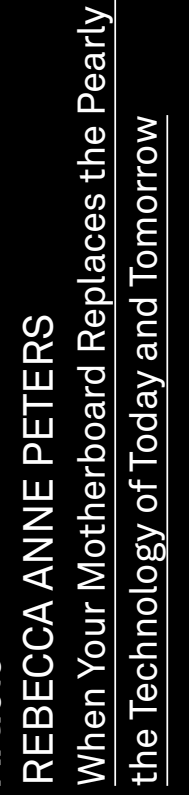

\section{$m$
$\dot{0} \dot{0}$
$\dot{0}$}


an amusement park created to carry out justice, yet because she does not remember the event itself, or even who she is, there is no ability for penance, as was often the aim of punishment when using the stocks or pillories. Instead, it is meant as a form of public control, a warning to others, and a means of perpetual torture in this life, presumably because it will not be carried out in the next, as religion teaches. This detail is also supported by the notion that suicide is depicted as a means of evading justice in the episode. That being said, this episode might also be considered from the perspective of eternal suffering, because Skillane is being punished in the same way day after day. However, the theme park's voyeuristic feel seems more in keeping with the notion of public punishment when we consider the history of Christianity. We will, however, consider the question of eternal suffering later in the subsection on "Men Against Fire."

The first book of the Bible lays the groundwork for the concepts of capital punishment. "Whoever sheds human blood, by humans shall their blood be shed; for in the image of God has God made mankind" (Genesis 9:6 NIV). Later in the Old Testament, public punishment is considered just. "The hands of the witnesses must be the first in putting that person to death, and then the hands of all the people. You must purge the evil from among you" (Deuteronomy 17:7 NIV). It is also important to distinguish in this case, however, between death and punishment, as we see that in the imagined future in "White Bear," death is not enough, and not the aim. The aim is retribution and we know this because they consider Skillane's accomplice to have evaded justice through death.

Further, we see that part of the test for what is to be viewed as an acceptable punishment is whether a judge - the final word on the matterdecides it:
"When people have a dispute, they are to take it to court and the judges will decide the case, acquitting the innocent and condemning the guilty. If the guilty person deserves to be beaten, the judge shall make them lie down and have them flogged in his presence with the number of lashes the crime deserves, but the judge must not impose more than forty lashes. If the guilty party is flogged more than that, your fellow Israelite will be degraded in your eyes" (Deuteronomy 25:1-3 NIV).

Later in the New Testament, we see that God grants authority to the state with regards to punishment:

"Let everyone be subject to the governing authorities, for there is no authority except that which God has established. The authorities that exist have been established by God. Consequently, whoever rebels against the authority is rebelling against what God has instituted, and those who do so will bring judgment on themselves. For rulers hold no terror for those who do right, but for those who do wrong. Do you want to be free from fear of the one in authority? Then do what is right and you will be commended. For the one in authority is God's servant for your good. But if you do wrong, be afraid, for rulers do not bear the sword for no reason. They are God's servants, agents of wrath to bring punishment on the wrongdoer" (Romans 13:1-4 NIV).

We also see in Job 34:26-27: "He punishes them for their wickedness where everyone can see them, because they turned from following Him and had no regard for any of his ways" (NIV). Thus, we can see that the 
concept of public punishment and torture is not only an ugly pock on the history of humanity, but something condoned throughout the Bible itself. Though there is a movement towards viewing punishment as a means of rehabilitation, that has not always been the case. If the culture of the time, in the case of the episode an imagined future with the technology for punishment of the kind depicted in "White Bear," has a criminal justice system which seeks retribution, and has the institutional authority to carry it out, a theme park of justice, as we see in this episode, somehow seems like a logical conclusion. Though Jesus called for turning the other cheek and loving one's enemies, he also suggests that those who do evil will rise to be condemned by his father (Matthew 5:38-48; John 5:29 NIV). If humans have become godlike through the use of technology, as we saw in the previous section, the role of god-like judge might also be one of those new powers, gained through technology and desired just as much as eternal life or omniscience.

As Skillane is put on display for the sake of derision, it is hard not to compare the practice to pillories or other forms of public punishment common to New England colonial life (Earle, [1896] 1995). We see Skillane booed and jeered at, told to "burn in hell," all while restrained to a wooden chair (Fig. 4). The comparison between the means of social control used by the Christian church of the time and the social control played out within the episode are startlingly clear: the wicked should be punished, and the righteous should play a role on the process; evil should be "purged" and let it be a warning to others. While discussing the idea of torture within the episode, Annabel Jones said, "[ $t]$ he focus is very much on how we bring people to justice and what outrages we can do if we feel we're morally justified" (Brooker and Jones 2018, 87).
Speaking of God's judgment and the just punishment for the wicked on earth, David writes in Psalm 58: 1011 , “[ $t$ ]he righteous will be glad when they are avenged, when they dip their feet in the blood of the wicked. Then people will say, 'Surely the righteous still are rewarded; surely there is a God who judges the earth"' (NIV). This concept of the righteous dipping their feet in the blood of the wicked seems particularly apt for the concept of public punishment in "White Bear," where the mob revels in the drama of the penance-for the theatrics just as much as the justice of it, as we saw was also the case in the discussion of colonial life above.

Other episodes that question concepts surrounding the role of public humiliation or judgment as a social control might include "The National Anthem" (2011), "Shut Up and Dance" (2016) or even "Crocodile" (2017). However, "White Bear" is the most relevant for this discussion given the combination of public punishment, criminal justice, and its near mirroring of Christian punishment in early colonial America.

Outcast, damned and condemned in "White Christmas" (2014) 8

- What does it mean, this register?

- It means you're blocked.

- By who?

- By everyone.

In "White Christmas" the characters live in a world where everyone has Z-Eyes (a device that connects users with the internet directly through their field of vision). The episode is made up of a series of stories within a larger one. After a bizarre turn of events in which one if his clients dies, Matt (Jon Hamm) a "dating coach" by night and "cookie" 


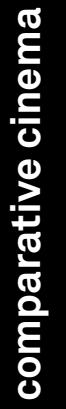

24

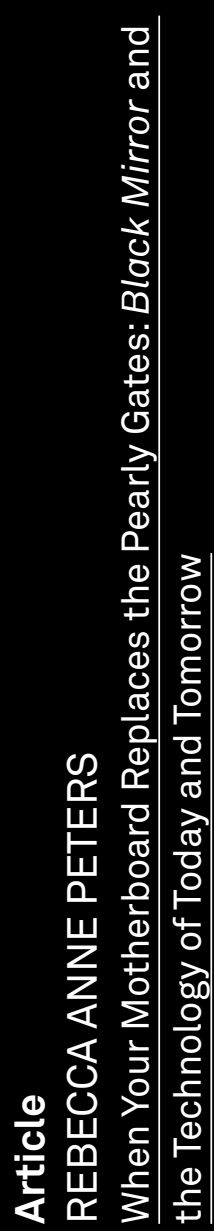

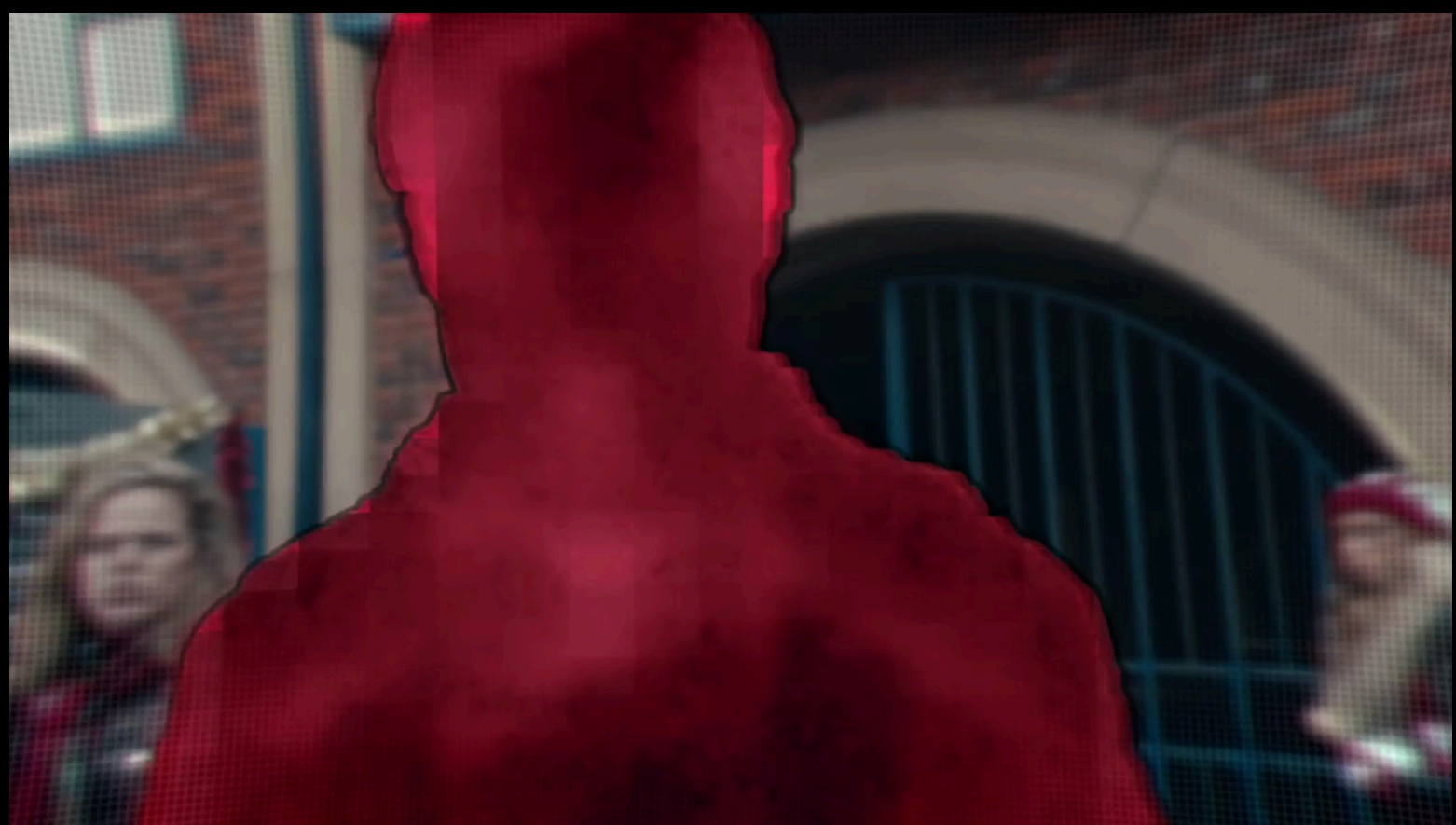

Fig. 5: "White Christmas," Black Mirror (2014)

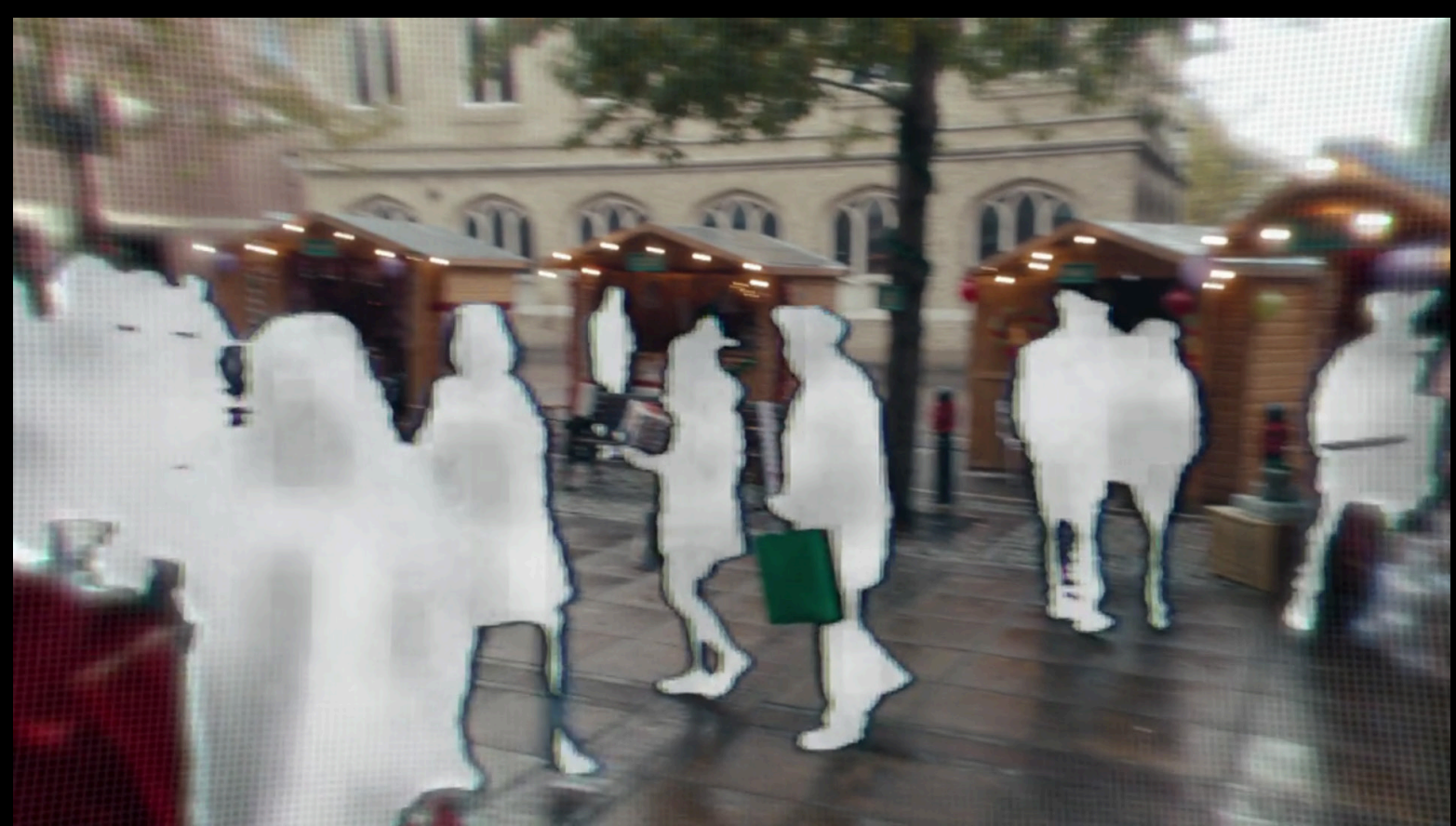

$\bar{\prime} \stackrel{\circ}{\circ}$ 운 운

Fig. 6: "White Christmas," Black Mirror (2014) 
specialist by day, assists police in helping them to get a confession in return for avoiding a jail sentence. Cookies are digital duplicates of a person-a microchip imbedded just below the skin near the temple that absorbs information and duplicates the consciousness of the individual. The technology in the episode is commercially used to basically function like a perfect smart house/personal assistant. Your digital copy works making everything just the way you like it-and they would know how, they are a perfect copy of you (a duplicate much like the digital versions we saw in "San Junipero"). Matt's job is to convince or coerce these duplicates into playing the role they have been created for. Matt's deal to help the police involves his coercion of another such cookie; this time he needs to get a confession from Joe (Rafe Spall) who was driven to murder after a series of events following a breakup, and his subsequent blocking by his ex-partner. However, at the end of the episode, although police hold up their end of the deal-with no jail time-Matt gets registered as a sex offender, and with the Z-Eye technology this means that others only see him as an ominous red blob (Fig. 5). He can no longer interact with anyone else, seeing others simply as "blocked" or greyed out blurs (Fig. 6). Essentially, Matt is ostracized.

In 1 Corinthians Chapter 5 we see Paul instruct the church to cast out those who are amoral; he writes: "[d]o not even eat with such people" and later, "God will judge those outside. 'Expel the wicked person from among you'" (1 Corinthians 5 NIV). This last expelling advice referring back to Deuteronomy, where the concept of purging the evil from the group is encouraged:

\section{"That prophet or dreamer} must be put to death for inciting rebellion against the Lord your God, who brought you out of Egypt and redeemed you from the land of slavery. That prophet or dreamer tried to turn you from the way the Lord your God commanded you to follow. You must purge the evil from among you" (Deuteronomy 13:5 NIV).

Elsewhere in Deuteronomy we see the same notion of purging, expelling, or casting out:

"They shall say to the elders, 'This son of ours is stubborn and rebellious. He will not obey us. He is a glutton and a drunkard.' Then all the men of his town are to stone him to death. You must purge the evil from among you. All Israel will hear of it and be afraid" (Deuteronomy 21:20-21 NIV).

\section{Z-Eyes in "White Christmas" let} people see their virtual connections through their field of vision, but it also means that those who are deemed criminals can be blocked from sight and sound, through technological ostracism, to help others keep a distance. Matt is even singled out as someone not just blocked, but outcast-his blur appears red to everyone who sees him. This technology, while on the surface seems far-fetched, is reflected in contemporary culture and the criminal justice system today; in many places in the United States sex offenders, of all types, are on public registries which include their addresses. Likewise, they are prohibited from living in many places, particularly within certain distances of schools and playgrounds; this also includes sex offenders who committed crimes that had nothing to do with children (McCullagh 2009).

More recently, some states within the United States have prohibited sex offenders from using social media as part of their parole conditions (McCullagh 2009). Today, this is the 
equivalent of ostracism. No LinkedIn to look for jobs; not even any news websites because their comment features could be considered social media. More recently, the United States Supreme Court ruled that the complete prohibition of social media use is unconstitutional because it limits the freedom of speech of the individual, similarly the UK ruled such laws as an unreasonable intrusion on civil liberties (Liptak 2017; Dalesio 2017; Thomson 2012). It is unclear the exact way the new US ruling will impact previous laws, but there is clearly public sentiment to push these individuals to the margins of society, one way or another. Of the punishment for Matt in "White Christmas" Brooker said, "[a] bit like someone with a conviction on their record, which you'd see if you were Googling them to employ them. So it's a hellish representation of that going on in real time" (Brooker and Jones 2018, 121). We see, similarly to the subsection above on "White Bear," that both forms of punishment, public torture and ostracism, aided by new technology become within the grasp of humanity on a new level, on par with an all-powerful god.

Other details in the episode are likewise interesting to consider through the lens of Christianity. The song, "I wish it could be Christmas every day" plays both at the beginning and end of the episode within the simulated world where Joe's cookie and Matt trade stories and where eventually, the stories that brought them both to where they are come out. Later, one police officer, when leaving for the day, changes the settings on the cookie, leaving Joe's digital duplicate in a digital purgatory alone, passing what will feel like a thousand years a minute. Their dialogue is as follows: "Just changing the time settings. Cranked him up to 1,000 years a minute. There's a proper sentence. Or do you want me to switch him off?" The other: "No. Leave him on for Christmas." Somehow, this sense of divine justice is considered even more satisfying on Christmas. Of this detail, Brooker said "[h]e's basically in a hell" (Brooker and Jones 2018, 121). Stuck in a perpetual nightmare, Joe's duplicate is heard screaming as the episode finishes. Another small detail that lets us know Brooker is thinking about these connections between the use of technology within the justice system in Black Mirror alongside biblical notions of justice.

This concept of eternal suffering will be considered in the next subsection through the study of a different episode that considers the concept more concretely because of its use as a threat to social compliance. Other episodes that reflect this idea of being socially ostracized, at least from a certain vantage point, might include "Shut up and Dance" (2016) or "Nosedive" (2016), though "White Christmas" has the most concrete use of the concept throughout the series.

\section{Eternal Suffering in "Men Against} Fire" (2016) ${ }^{9}$

- Is this what you want? On a loop? In a cell all alone?

$$
\begin{aligned}
& \text { - [whimpers] } \\
& \text { — We can make that go away. }
\end{aligned}
$$

Seeing the world through the technological enhancements of their military implants, called MASS, the main characters in "Men Against Fire" are a group of soldiers fighting against an infestation of "roaches" (short for cockroaches), terrifying screeching monsters with waxy skin and pointed teeth. The military implants help the soldiers to have otherwise superhuman powers - they can see directly through drone camera, they are able to see blueprints of buildings, and they see their mission details-all without doing a thing. However, after a round of cleaning up cockroaches, 


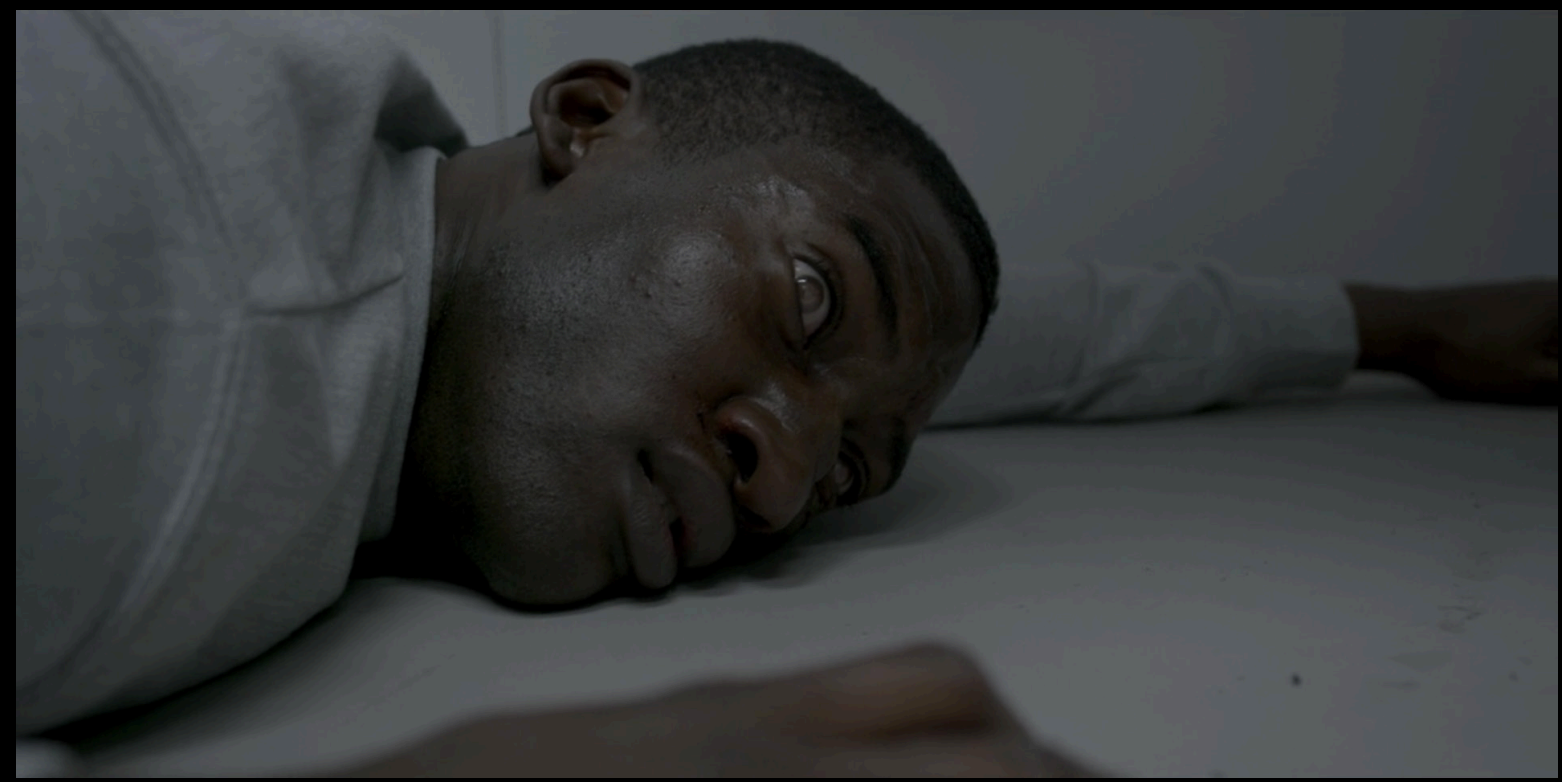


Koinange (Malachi Kirby), nicknamed Stripe, starts having problems with his MASS, and he begins to realize that his enhancements are a little more extensive than he realized. They inhibit his ability to smell, his ability to hear everyday details, and most importantly, they create the illusion of the monstrous roaches-blocking out the screams and adding screeches, limiting the smell of blood and death and changing the faces of normal humans to something of nightmaresall to eradicate "bad blood." Koinage's captain puts it this way: "the sickness they're carrying. That doesn't care about the sanctity of life or the pain about who else is going to suffer."

Described as his "war movie," "Men Against Fire" certainly shows us a side to war: the dehumanization of the enemy, the constant attempt to create soldiers who are not "weakened" by their humanity and empathy, and most importantly the absurdity as to where we draw lines between ourselveshow we justify our constant desire to eradicate the other. Brooker asks us to look within ourselves at the end of the episode when Stripe is offered the choice to suffer on a loop, reliving the murders he unknowingly committed, or to get it all erased and keep killing. Would we, if we found ourselves in the same situation, live in a constant loop, reliving the real footage of a series of murders unknowingly committed, or instead go back to seeing things simply as human versus monster? It seems like an impossible decision. However, in the end, there is only one choice we are likely to make. Though the seemingly moral decision would be to stop the killing, to live with what we have done, it is rendered unimaginable by the constant re-play made possible by the technology implanted into the soldier's eyes and sensory input.

In "Men Against Fire" we see neverending, immersive punishment on a loop for a soldier who refuses to be compliant (Fig. 7). We can see that eternal suffering is a deterrent; it works as a means of control. "He will punish those who do not know God and do not obey the gospel of our Lord Jesus. They will be punished with everlasting destruction and shut out from the presence of the Lord and from the glory of his might" (2 Thessalonians 1:8-9 NIV). Then, in the episode the concept of eternal suffering is not inflicted with the same criteria as described in the Bible, but with the same goal-compliance.

If we consider the use of this kind of torture as a means of compliance, we can see how it connects back to the use of ostracism as an assertion of group norms as considered in the last subsection. The three forms of punishment in Black Mirror considered in this article each have slightly different aims, but all reflect the assuming of god-like powers by society as a means of social control. Though the church has played a role in social control throughout the history of Christianity, much like many other religions, suddenly we see a world where compliance can be sought for less than pure motives, as is the case in "Men Against Fire." It is as if Brooker is asking us in each episode relating to punishment, "Does this person deserve to be punished in this way?" while making us less and less sure of our answers each time.

The depiction of the enemy as beastlike is not far from biblical concepts of eternal suffering either.

"A third angel followed them and said in a loud voice: 'If anyone worships the beast and its image and receives its mark on their forehead or on their hand, they, too, will drink the wine of God's fury, which has been poured full strength into the cup of his wrath. They will be tormented with burning sulfur in the presence of the holy angels and 
of the Lamb. And the smoke of their torment will rise for ever and ever. There will be no rest day or night for those who worship the beast and its image, or for anyone who receives the mark of its name"' (Revelation 14:9-11 NIV).

Likewise, the doubling of the same footage with and without the filter of the MASS implant reinforces the demonization of the undesirable people, we see them first as they are imagined through the society in the episode, and then as they would appear to us. We could relate this to any number of mass killings and genocides in which propaganda was meant to demonize the "undesirable" other. Likewise, the killing of "witches" in colonial America might also serve as an interesting comparison given the hysteria seen in both the episode and the historical events. Though the average villagers in the episode cannot distinguish roaches from normal people, they are unwilling to even eat the food that might have been touched by them; this level of hysteria and mass illusion of difference is on par with the hysteria seen in the witch trials run by religious puritans.

Other episodes that touch on this concept of eternal suffering include, as mentioned above, "White Bear" (2013) and "White Christmas" (2014), but other episodes like "USS Callister" (2017) and "Black Museum" (2017) also bring up the idea in regards to future uses of technology related to suffering.

\section{Conclusion}

Taken together, the five episodes of Black Mirror, as considered in this article build an interesting argument towards the consideration of the relationship between technology and the traditional role of religion. The television series as a whole explores our obsession with, and trust in, technology. It also looks at how that trust can easily break down into a future where technology is no longer a tool, but a mechanism of control.

We have seen that beyond the five episodes discussed in this article, there are numerous others that could be examined for their relationships to the Christian concepts highlighted. Likewise, each episode deserves further analysis through this framework in much greater depth. It is important to emphasize again that this article was by no means attempting to exhaustively analyze all possible interpretations of Black Mirror in regards to the question of the specter of religion; instead, the aim has been to map an argument as to why the show might be contemplated using this model, as a general framework of consideration.

It seems clear that when viewed together, this grouping of episodes from Black Mirror asks questions about the relationship between seemingly abandoned Christian concepts, and our potential uses of technology. Together they build a convincing argument that Brooker himself asks these questions about the specter of religion. So, what is to prevent us from following the same path as the societies in some of the Black Mirror episodes considered here? Brooker seems to be telling us that not much stands in our way, technologically or culturally speaking. Everlasting life, predicting the future-those things could be great; but on the other hand, public punishment, ostracism, and eternal suffering do not hold the same lure. Technology, as we have seen throughout these episodes of Black Mirror, as well as in the world around us, holds great potential, but it also holds dangerous possibilities as well. 
1/ Throughout this text the capitalized God will be used to refer specifically to the biblical Christian deity, whereas god or gods will be used in the rare instances where the concept of a deity in a more general sense is considered.

2/ Retrieved from https://www.youtube.com/watch?v=U2YPxSDloPE [accessed March $23,2020]$

3/ For these reasons, this paper will use Christian concepts instead of those from other religions, although it is possible that these comparisons could be made using other belief structures as the point of comparison. In addition, when considering a concept that is exclusive to a particular branch within Christianity (Protestantism, Catholicism, Eastern Christianity, etc.) the denominational reference will be given to clarify that it is a concept particular to a specific branch. Largely, the focus of this paper will be placed on Western Christian concepts specific to Catholicism and Protestantism, as well as the many denominations considered to fall within Protestant belief.

4/ Episode directed by Owen Harris. First aired on Netflix on October 21, 2016.

5/ Episode directed by Tim V. Patten. First aired on Netflix on December 29, 2017.

6/ Put simply Calvinists believe that the only logical way for God to be all-knowing is for him to have preordained all of history, in other words and quite crudely put, there are those who have been elected to be saved, and those who have not-the damned; they argue that this preordained history does not exclude free will. On the other side of the argument, Arminianists, believing that the Calvinist model lacks the notion of true free will, instead advocate for a model of God outside of time as a possible means to reconcile the combination of an all-knowing God and true free will. Thus, God can be understood to be omniscient because for him everything is happening simultaneously, since he is outside of time; in this way, the idea of an all-knowing God and free will can co-exist.

7/ Episode directed by Carl Tibbets. First aired on Channel 4 on February 18, 2013.

8/ Episode directed by Carl Tibbets. First aired on Channel 4 on December 16, 2014.

9/ Episode directed by Jakob Verbruggen. First aired on Netflix on October 21, 2016.

\section{Bibliography}

Beilby, James K. and Paul R. Eddy. eds. 2001. Divine Foreknowledge: Four Views. Downers Grove, IL: InterVarsity Press.

Benedikt, Michael. ed. 1991. Cyberspace: First Steps. Cambridge, Massachusetts: MIT Press.

Bessel, Richard. 2015. Violence: A Modern Obsession. London: Simon \& Schuster.

Bowler, Kate. 2018. Blessed: A History of the American Prosperity Gospel. New York: Oxford University Press.

Boyd, Gregory A. 2001. "The Open Theism View.” In Divine Foreknowledge: Four Views, edited by James K. Beilby and Paul R. Eddy, 13-47. Downers Grove, IL: InterVarsity Press.

Brooker, Charlie. 2011. "Charlie Brooker: the dark side of our gadget addiction." The Guardian, December 1, 2011.https://www.theguardian.com/ technology/2011/dec/01/charlie-brooker-dark-side-gadget-addiction-blackmirror [accessed March 23, 2020] 
Press.

Constant, Sarah J. 2018. "Heterotopias and Utopias in Black Mirror: Michel Foucault on 'San Junipero'.' In Black Mirror and Critical Media Theory, edited by Angela M. Cirucci and Barry Vacker, 213-22. London: Lexington Books.

Dalesio, Emery P. 2017. "Supreme Court weighs law banning sex offenders from Facebook." AP News, February 26, 2017. https://apnews. com/9f84e0d20ea54dfcaab94d60542d837a [accessed March 26, 2020]

Drage, Eleanor. 2018. "A Virtual Ever-After: Utopia, Race, and Gender in Black Mirror's 'San Junipero'.' In Black Mirror and Critical Media Theory, edited by Angela M. Cirucci and Barry Vacker, 27-39. London: Lexington Books.

Durrant, Russil and Zoe Poppelwell. 2017. Religion, Crime and Punishment: An Evolutionary Perspective. Cham: Palgrave Macmillan.

Earle, Alice M. [1896] 1995. Curious Punishments of Bygone Days. Bedford, MA: Applewood Books.

Harari, Yuval Noah. 2014. Sapiens: A Brief History of Humankind. London: Vintage.

2016. Homo Deus: A Brief History of Tomorrow. London: Vintage.

Hayles, N. Katherine. 1999. How We Became Posthuman: Virtual Bodies in Cybernetics, Literature, and Informatics. Chicago: The University of Chicago Press.

Holy See Press Office. 2018. "New revision of number 2267 of the Catechism of the Catholic Church on the death penalty - Rescriptum 'ex Audentia SS.mi."' Summary of Bulletin, August 2, 2018. https://press.vatican. $\mathrm{va/content/salastampa/en/bollettino/pubblico/2018/08/02/180802a.html}$ [accessed March 26, 2020]

Jones, Mark and Peter Johnstone. 2015. History of Criminal Justice. 5th ed. Amsterdam: Routledge.

Liptak, Adam. 2017. "A Constitutional Right to Facebook and Twitter? Supreme Court Weighs In." The New York Times, February 27, 2017.https:// www.nytimes.com/2017/02/27/us/politics/supreme-court-north-carolinasex-offenders-social-media.html [accessed March 26, 2020]

Mahon, Peter. 2018. Posthumanism: A Guide for the Perplexed. London: Bloomsbury Academic.

McConville, Sean. ed. 2003. The Use of Punishment. London: Routledge.

McCullagh, Declan. 2009. "Kicking Sex Offenders Off The Internet?" CBS News, August 13, 2009. https://www.cbsnews.com/news/kicking-sexoffenders-off-the-internet/ [accessed March 26, 2020]

Moorman, Mary C. 2017. Indulgences: Luther, Catholicism, and the Imputation of Merit. Steubenville, Ohio: Emmaus Academic.

Moravec, Hans. 1988. Mind Children: The Future of Robot and Human Intelligence. Cambridge, Massachusetts: Harvard University Press.

Roden, David. 2015. Posthuman Life: Philosophy on the Edge of the Human. London: Routledge. 
Russell, William R. ed. 2017. The Ninety-Five Theses and Other Writings. New York: Penguin Books.

Smith, Samuel. 2018. "Mennonite Seminary Demotes President, Ousts Megachurch Pastors Serving as Lecturers." The Christian Post, September 7, 2018. https://www.christianpost.com/news/mennonite-seminarydemotes-president-ousts-3-megachurch-pastors-serving-as-lecturers.html [accessed March 26, 2020]

Snyder, T. Richard. 2000. The Protestant Ethic and the Spirit of Punishment. Grand Rapids Michigan: William B. Eerdmans Publishing Company.

Thomson, lain. 2012. "Sex offenders need internet access, judge rules: Banning online access 'unreasonable'." The Register, November 14, 2012. https://theregister.co.uk/2012/11/14/internet_access_human_right/ [accessed March 26, 2020]

Wertheim, Margaret. 2000. The Pearly Gates of Cyberspace: A History of Space from Dante to the Internet. New York: W. W. Norton \& Company, Inc. 